\title{
慢性呼吸器感染症に和ける低分子免疫調節剤
}

\section{Forphenicinol の使用成績}

\author{
虎の門病院呼吸器科 \\ 吉村 邦彦 蝶名林直彦中谷 龍王 \\ 中森 祥隆 中田紘一郎 谷本 普一
}

（昭和 60 年 4 月 2 日受付）

(昭和 60 年 5 月 13 日受理)

Key words : Forphenicinol, Immunomodulator, Chronic respiratory infections

\section{要旨}

低分子免疫調節剤 Forphenicinol の慢性呼吸器感染症患者に対する臨床効果および免疫学的効果を検 討した。対象は 9 例の気道・中間領域感染症で, 基礎疾患の内訳はびまん性汎細気管支炎 (DPB) 8 例, 気管支拡張症 1 例であり, 感染起炎菌はPSeudomonas aeruginosa 7 例, ブドウ糖非発酵グラム陰性桿菌 $(G N F-G N R) 2$ 例であった。 また本剤は経口投与され，その投与日数は平均 357 日，総投与量は平均 31.8 $\mathrm{g}$ であった。

1. 臨床効果は, 有効 1 例，やや有効 4 例で，やや有効以上の有効率は $55.6 \%$

2. 細菌学的には全例で不変であった。

3. 副作用ないし検査値異常は 1 例も認められなかった。

4. 免疫学的検査では, T, B リンパ球比率には有意な変化は認められなかったが, Tリンパ球サブセッ トのらち本剂投与によりサプレッサーT 細胞の減少傾向が認められた。 たた，NK 細胞活性も本剂投与 前後で有意な変化を示さなかったが，4例で軽度の上昇が認められた。

以上より, Forphenicinol はサプレッサーT 細胞の減少により抗体産生能の増強効果が推測され，かつ 安全性が高く長期投与が可能なため, 慢性呼吸器感染症に対し有用であることが示唆された.

\section{1. 緒言}

梅沢らにより発見された Forphenicinol〔L-2(3-hydroxy-4-hydroxymethylphenyl) glycine, M.W. 197.19]は, ニワトリ小腸アルカリフォス ファターゼの阻害物質として放線菌培養沪液より 見出された Forphenicine ${ }^{1) 2}$ の誘導体であり（Fig. 1)，経口投与の可能な低分子免疫調節剤であ る3)4. 本剂はアルカリフォスファターゼは阻害し ないが，マウスに拈ける遅延型過敏症の増強， マ クロファージの貧食能の亢進, 移植腫瘍に対する 増殖抑制, P. aeruginosa 感染症に対する防御効果 などの生物活性を有し，かつ極めて毒性の低い物

別刷請求先：（元105）東京都港区虎ノ門 2-2-2 虎の門病院呼吸器科

吉村 邦彦
質であることが証明されている5)6).

われわれはForphenicinol を主としてP. aer uginosaによる慢性呼吸器感染症症例に投与し, 本剂の長期連続投与の臨床効果とその安全性の検 討を行ったが，さらに免疫学的に興味ある知見を 得たので報告する。

本剂を投与するにあたり，これら対象症例に沶

Fig. 1 Structures of Forphenicinol and Forphenicine

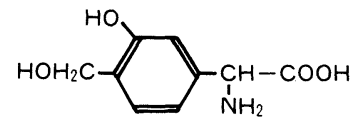

Forphenicinol

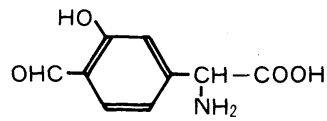

Forphenicine 
ける基礎疾患の重症度は原則として中等症以下と したが，9例中びまん性沉細気管支炎 4 例では, 酸素療法も施行されていた。な拉対象患者には本 研究の主旨を説明し，同意を得た上で実施した。

\section{2. 対象および方法}

1) 対象

1983年 5 月より 1984 年 12 月までの期間に当科に て経験した慢性気道・中間領域感染症 9 例を対象 とした（Table 1).

基礎疾患の内訳はびまん性汎細気管支炎（以下 DPB と略) 8 例，気管支拡張症（以下 BE と略）

1 例であり，性別は男性 6 例，女性 3 例，また年 齢は31〜82歳, 平均64.2歳であった. Forphenicinol 投与開始前からコルチコステロイド剤 (CS) が投与されていたのは症例 5 和よび 7 の 2 例で あり, 症例 4 では本剂投与開始約 1 力月後より CS が投与された。

気道・中間領域感染症の起炎菌は Mucoid 型を 含めた $P$. aeruginosa 7 例（全例 $\mathrm{DPB}$ ), ブドウ 糖非発酵グラム陰性桿菌（GNF-GNR と略） 2 例 （DPB 1 例，BE 1例)であった。な拉，起炎菌に ついては喀痰培養で培地の $1 / 3$ 以上に生育した病 原性細菌とした。

2) 方法

これら 9 例の対象患者に対し萬有製薬（株）よ り提供された Forphenicinol を1983年 5 月より 1 日 1 回早朝空腹時に経口的に投与した。 1 日投与 量は症例 1 が50mg で, 他の 8 例は全て $100 \mathrm{mg}$ で あった。投与期間は30～563日，平均357日でほぽ 1 年間投与を継続したことになるが，疾患別にみ ると DPB 8 例の平均が375日，BE 1 例で208日 と，DPBに対する投与がより長期にわたってい た. また総投与量は $3.0 〜 56.2 \mathrm{~g}$, 平均 $31.8 \mathrm{~g}$ であっ た。な扮投与継続中の症例は 4 例であるが，これ らの症例については1984年12月 1 日現在の状態に より評価を行った。

Forphenicinol の臨床効果および安全性の検討 のため, 定期的に自他覚所見, 胸部 X 線所見を確 認し，少なくとも月 1 回以上の一般検査ならびに 喀痰の細菌学的検查を施行した他, さらに免疫学 的指標として末梢リンパ球およびTリンパ球サ

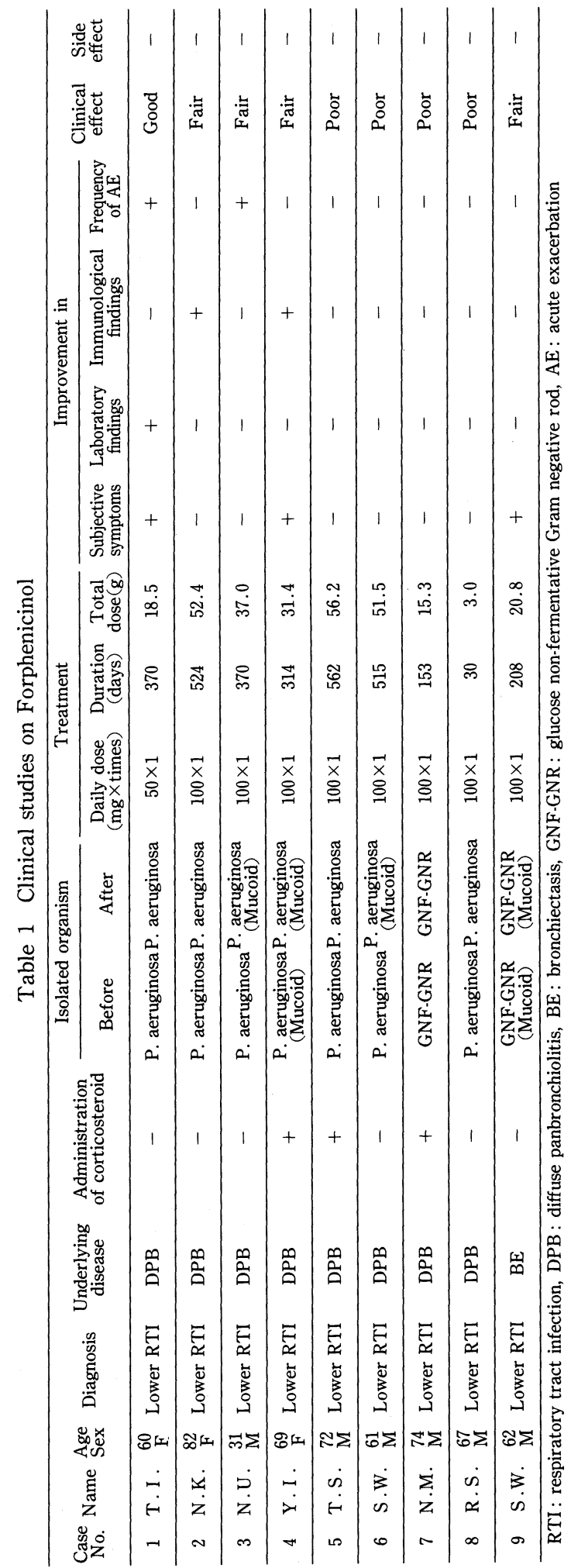


ブセットの推移と, 末梢血中の Natural killer （NK）細胞活性も経時的に測定した。

末梢血の T抽び B リンパ球分画は $\mathrm{E}$ 抢よび $\mathrm{EAC}$ ロゼット法, T リンパ球サブセットは Ortho 社の $\mathrm{OK}$ シリーズモノクローナル抗体を用い, レーザーフローサイトメトリーによる直接免疫蛍 光法にて OKT 3，4，8陽性細胞を測定し OKT 4/ OKT8比を算出した。また NK 細胞活性は培養 K562細胞を標的細胞とし，ェフェクタ一細胞と 50：1の比で反応させた後, \% cytolysis を求め る ${ }^{51} \mathrm{Cr}$ 遊離法にて測定した。

な括これらリンパ球に関する免疫学的測定は東 京クリニカルラボラトリ一社に依頼した。

また, 得られた検査成績の推計学的検討には paired t-testを用いた。

3）効果判定基準

本剂の臨床効果判定では, 1) 咳, 痰, 呼吸困難, 日常生活動作などの自覚症状の改善,2）一般検査 所見の改善，3）免疫学的検查所見の改善，4）本 剤使用後の急性増悪回数の減少, の 4 項目を指標 とし, 細菌学的検查所見之胸部 X 線所見は参考に とどめた。

以上の 4 項目中， 3 項目以上にわたって改善が 認められたものを有効，1ないし 2 項目に改善が 認められたものをやや有効, それ以外を無効と判 定した。

\section{3. 成 績}

1）臨床効果
先に述べた効果判定基準による判定では，臨床 効果は有効 1 例(11.1\%), やや有効 4 例(44.4\%) 無効 4 例 (44.4\%) であった（Table 1).

通常の抗生物質などと異なる本剤の特異性を考 慮すると, ある程度の有効性が認められたやや有 効以上の有効率は 9 例中 5 例， $55.6 \%$ であった。 また, 細菌学的には, 全例で $P$. aeruginosaないし GNF-GNR は持続して検出された。

2) 副作用

本剂による特記すべき副作用は 1 例も認められ なかった（Table 1).

3）一般検查成績（Table 2)

本剂に起因したと考えられる検査值異常は 1 例 も認められなかった。症例 1 および 7 で投与後の ALPがそれぞれ10.3，12.4 (K.A.U) と高值を示 したが，これらは骨粗鬆症などに起因する骨由来 のALP と考学られ，本剤との因果関係は否定的 であった。

4）免疫学的検査所見

Forphenicinol 投与開始前後の末梢血中リンパ 球サブセットの変化をTable 3に示す．T和よび

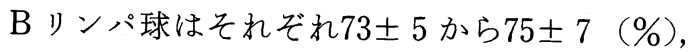
$25 \pm 5$ から $22 \pm 6$ （\%）と本剤投与による有意な 変化は認められなかった。ささに Tリンパ球サブ セットではOKT4陽性細胞は45土10から $44 \pm 10$ （\%）と不変であったが，OKT8陽性細胞では $25 \pm 9$ から $22 \pm 8(\%)$ と減少する傾向 $(\mathrm{p}<0.1)$ が 認められた。これらから算出したOKT4/OKT8

Table 2 Laboratory findings before and after the treatment with Forphenicinol

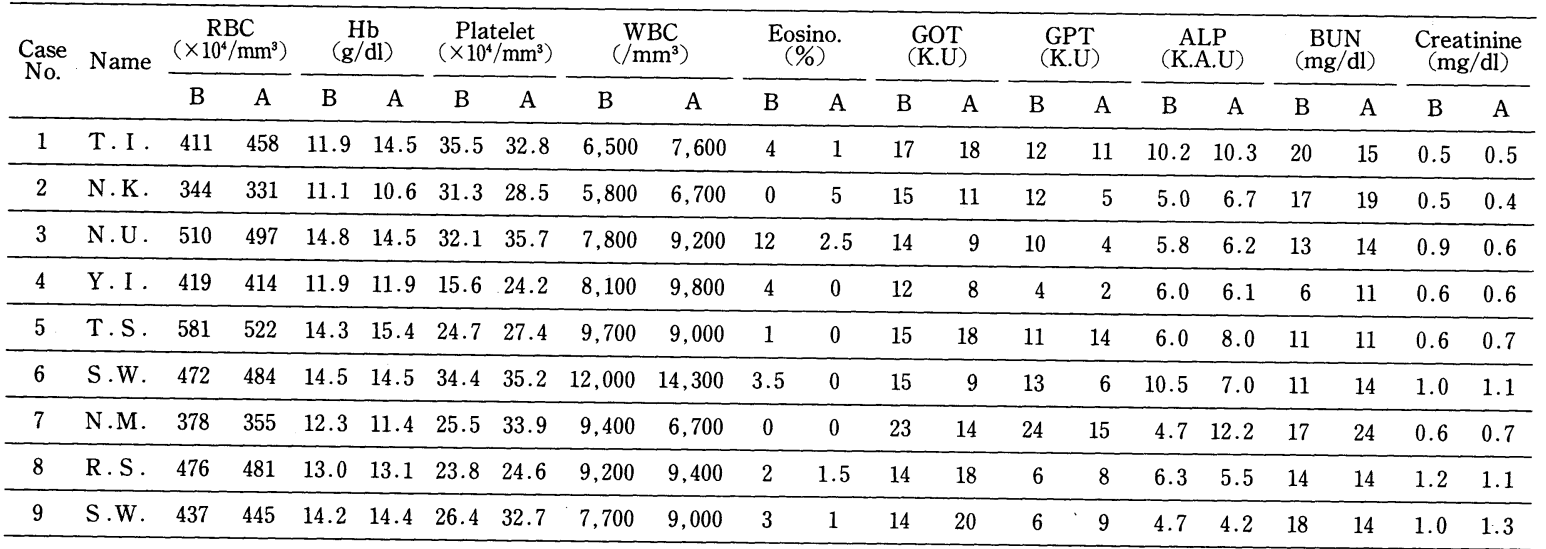


Table 3 Lymphocyte subpopulations and natural killer cell activity before and after the treatment with

Forphenicinol

\begin{tabular}{|c|c|c|c|c|c|c|c|c|c|c|c|c|c|}
\hline \multirow{2}{*}{$\begin{array}{l}\text { Case } \\
\text { No. }\end{array}$} & \multirow{2}{*}{ Name } & \multicolumn{2}{|c|}{$\mathrm{T}$ cell $(\%)$} & \multicolumn{2}{|c|}{ B cell $(\%)$} & \multicolumn{2}{|c|}{$\mathrm{OKT}^{+}(\%)$} & \multicolumn{2}{|c|}{$\mathrm{OKT}^{+}(\%)$} & \multicolumn{2}{|c|}{ OKT4/OKT8 } & \multicolumn{2}{|c|}{$\begin{array}{l}\text { NK cell (\%) } \\
\text { activity }\end{array}$} \\
\hline & & $B$ & A & B & A & B & A & B & A & B & $\mathrm{A}$ & $\mathrm{B}$ & A \\
\hline 1 & T. I. & 69 & $-*$ & 29 & - & 52 & 44 & 21 & 39 & 2.4 & 1.1 & 53.5 & - \\
\hline 2 & N.K. & 76 & 86 & 24 & 12 & 70 & 64 & 18 & 12 & 3.8 & 5.3 & 65.9 & - \\
\hline 3 & N.U. & 75 & 69 & 23 & 27 & 44 & 31 & 24 & 24 & 1.8 & 1.2 & 29.1 & 43.7 \\
\hline 4 & Y.I. & 67 & 67 & 29 & 30 & 42 & 38 & 48 & 21 & 0.8 & 1.8 & 63.8 & 25.8 \\
\hline 5 & T.S. & 67 & 81 & 30 & 16 & 41 & 50 & 26 & 28 & 1.5 & 1.7 & 74.5 & 75.9 \\
\hline 6 & S.W. & 78 & - & 20 & - & 36 & 36 & 28 & 18 & 1.2 & 2.0 & 69.6 & - \\
\hline 7 & N.M. & 74 & 68 & 25 & 29 & 50 & 54 & 22 & 22 & 2.2 & 2.4 & 70.0 & 62.6 \\
\hline 8 & R.S. & 69 & 74 & 28 & 23 & 37 & 35 & 12 & 9 & 3.0 & 3.8 & 62.3 & 68.0 \\
\hline 9 & S.W. & 84 & 80 & 14 & 20 & 37 & 41 & 27 & 28 & 1.3 & 1.4 & 70.6 & 74.3 \\
\hline \multicolumn{2}{|c|}{ mean $\pm \mathrm{SD}$} & $73 \pm 5$ & $75 \pm 7$ & $25 \pm 5$ & $22 \pm 6$ & $45 \pm 10$ & $44 \pm 10$ & $25 \pm 9$ & $22 \pm 8$ & \multicolumn{2}{|c|}{$2.0 \pm 0.92 .3 \pm 1.3$} & \multicolumn{2}{|c|}{$.1 \pm 13.0 \quad 58.4 \pm 18.0$} \\
\hline \multicolumn{2}{|c|}{$\mathrm{p}^{* *}$} & \multicolumn{2}{|c|}{$\mathrm{NS}^{* * *}$} & \multicolumn{2}{|c|}{ NS } & \multicolumn{2}{|c|}{ NS } & \multicolumn{2}{|c|}{$\mathrm{p}<0.1$} & \multicolumn{2}{|c|}{ NS } & \multicolumn{2}{|c|}{ NS } \\
\hline
\end{tabular}

${ }^{*}$ not examined, ${ }^{* *}$ paired t-test, ${ }^{* * *}$ not significant

比は2.0土0.9から $2.3 \pm 1.3$ とやや増加したが有意 ではなかった。

また，NK 細胞活性は投与前 $62.1 \pm 13.0(\%)$ か ら投与後 $58.4 \pm 18.0$ （\%）と全体では有意な変化 を示さなかったが軽度の上昇が 6 例中 4 例に認め られた。な拉，投与前の NK 細胞活性は大半が健 常者之同等であり, 低下例は症例 3 の 1 例のみで あった (Table 3).

5) 症例呈示

症例 4 : Y.I. 69歳, 女性

家族歴：母親 脳卒中, 長兄 肺結核にて死亡. 既往歴：17歳および27歳 慢性副鼻腔炎手術, 契煙歴はなく, とくに刺激性ガスの吸入歴もない. 現病歴：40歳頃より咳，痰が出現，1975年（60 歳)某病院に入院し慢性気管支炎の診断を受けた。 その後も症状が軽快せず，1979年 2 月当院初診, 入院精查により DPB と診断された。初診時喀痰 より Haemophilus influenzae が検出されたが, 同 年10月より P. aeruginosa に菌交代し，以後持続 的に検出された。 その後, 呼吸困難が徐々に増強 し，また気道および中間領域感染症の増悪を繰り 返したため各種の抗生物質を投与され，入退院を 繰り返した。1982年10月より家庭酸素療法を開始 したが, 呼吸困難が増強し食思不振も著明なため,
1983年 3 月 17 日，第 3 回目の入院となった.

入院後経過 (Fig. 2)：入院時呼吸困難は HughJones $\mathrm{V}$ 度と高度で, 大気下での $\mathrm{PaO}_{2}$ が38torr と著明な低酸素血症を呈していた。 また体温は $38^{\circ} \mathrm{C}$ を越光, 痰量も約 $150 \mathrm{~g} /$ 日と多量であった。喀 痰からは Mucoid 型の P. aeruginosa が検出され たため, 同菌に抗菌力を有する抗生物質の投与と, また酸素投与や輸液などの全身的治療を開始し た。胸部 X線写真では全肺野に小粒状影をみと め, 肺野の過膨脹所見和よび tram line が高度で あった (Fig. 3)。症状がようやく安定した 5 月19 日より Forphenicinol $100 \mathrm{mg}$ を経口にて投与開 始した。 また本剤投与開始後，6月に入り食思増 進と呼吸困難の軽減を目的としてBetamethasone の投与を開始し以後継続投与した。本剂投与開始 後も呼吸困難の程度は著変なく, 常時鼻カニュー ラによる 1.0 1.5 l/分の酸素吸入を要し, $\mathrm{PaO}_{2} 60$ 〜 $70, \mathrm{PaCO}_{2} 50$ 5 5torr の動脈血ガス所見であっ た. 下気道感染症に対して Fig. 2の如く多種の抗 緑膿菌抗生物質が投与されたが,一日痰量は約 100 $\sim 150 \mathrm{~g}$ /日と多く, 前述のように喀痰からは Mucoid 型 P. aeruginosa が持続的に（H）（卅）検出さ れ, CRPもその時々の炎症状態を反映して変動し た。しかし, 自覚的には発熱も軽微で, 他の症状 
Fig. 2 Clinical course of case 4 (Y.I. 69y. Female)

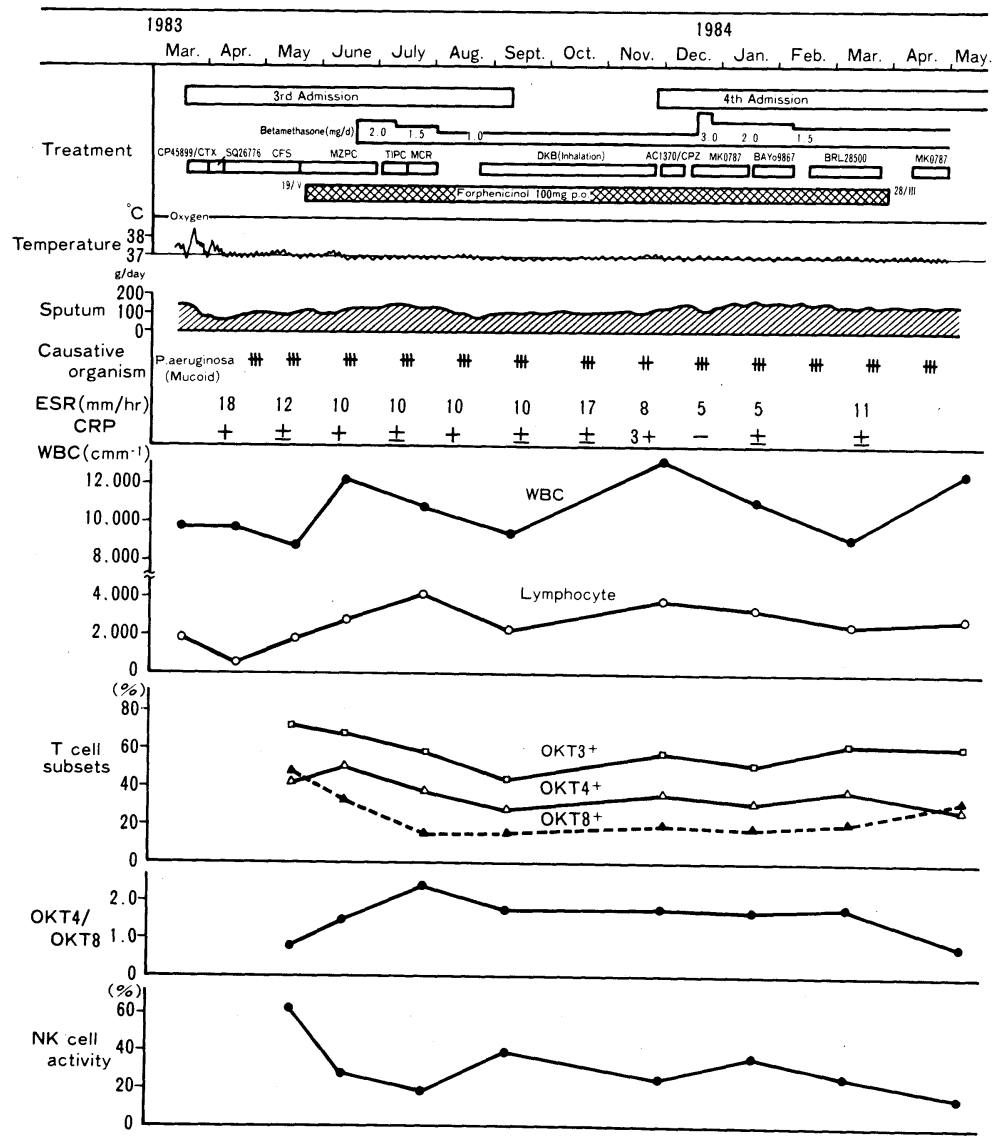

も長期にわたり安定しており，Forphenicinolの 効果が推測された。 その後 9 月 10 日退院となった が，11月に入り再度呼吸困難の増強，喀痰量の増 加がみられたため同月24日第 4 回目の入院となっ た。前回と同様に, 各種抗生物質, 酸素吸入, 輸 液などの治療を開始した。呼吸不全の状態は以前 に比し悪化して扣り, 鼻カニューラ $2.0 \mathrm{l} /$ 分吸入下 で $\mathrm{PaO}_{2} 60, \mathrm{PaCO}_{2}$ 54torr であった。

Forphenicinol はこの間も継続投与されており, とくに副作用和よび検査值異常の出現を見るこ となく, 翌1984年 3 月28日に原病の進行に伴う全 身状態の悪化のため中止するまで述べ314日，総 量 $31.4 \mathrm{~g}$ が投与された. Fig. 4は投与中止後の胸 部 X 線写真であるが，投与前 (Fig. 3) に比し有 意な変化を認めない. Fig. 2の下半に本症例の末 梢血中の白血球, リンパ球の絶対数, Tリンパ球
サブセットおよびOKT4/OKT8比，さらに NK cell 活性の経時的変化を図示した. 白血球総数は コルチコステロイド (CS) の投与と感染の増悪の ためほぼ常時増多の傾向を示したが, リンパ球数 も Forphenicinol 開始後 CS の投与にも拘らず減 少せず2,000〜4,000 $\left(\mathrm{cmm}^{-1}\right)$ の值をとった。さ らにTリンパ球サブセットでは本剂開始後, OKT3陽性細胞は一時減少しその後注 $60 \%$ 前後 に安定していたが，OKT4陽性細胞の相対的な増 加と, それに相反して OKT8陽性細胞の減少が認 められ, OKT4/OKT8比すなわちへルパー/サプ レッサーT細胞比はこれに伴って0.8から最高 2.4 まで上昇しかつ約 1.8 前後を維持した。 その後 本剂の中止によりこれら Tリンパ球サブセット は投与前の状態に復した。

一方, 本症例におけるNK細胞活性はForphe- 
Fig. 3 Chest X-ray film of case 4 before the treatment with forphenicinol (Mar. 18, 1983)

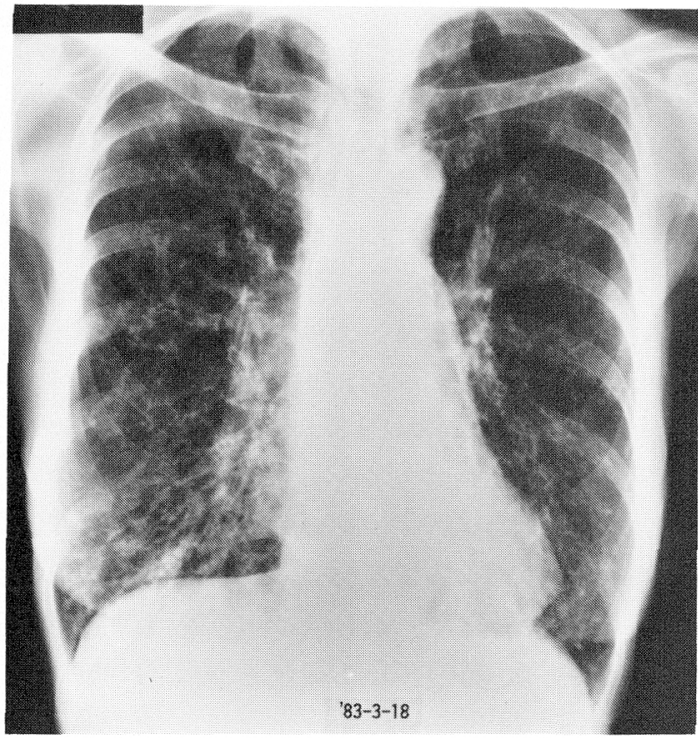

Fig. 4 Chest X-ray film of case 4 after the treatment with forphenicinol (Apr. 17, 1984)

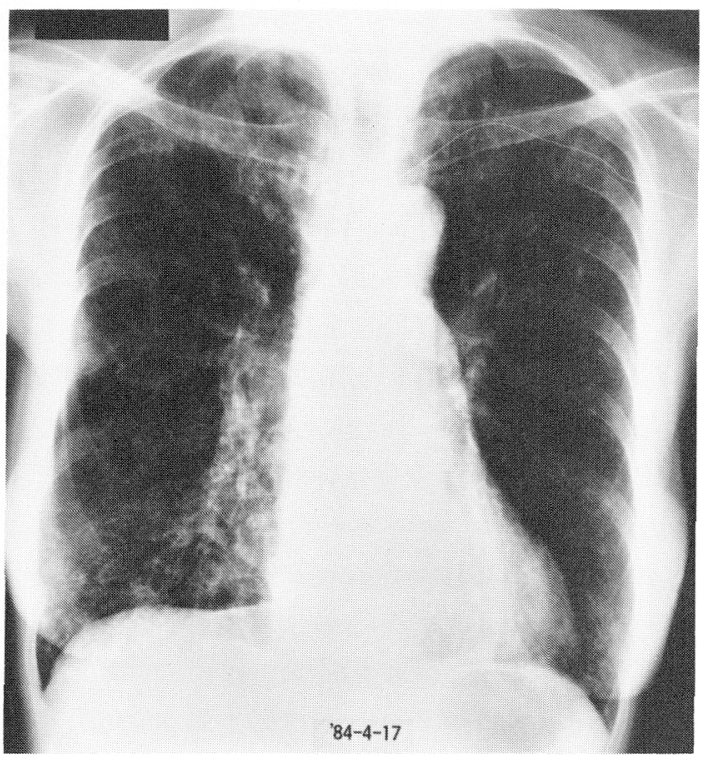

nicinol 投与開始前 $63.8 \%$ より, 投与開始後低下し, 以後も約20〜 40\%であった。これは，CS 投与およ び原疾患であるDPBの進行和よび憲化の関与が むしろ示唆され，本剂之の直接因果関係は否定的 と考光られた。
本症例での Forphenicinol の総合的な臨床効果 についてはやや有効と判定したが，その根拠は， 本剂投与開始後自覚症状が比較的長期にわたって 安定し，かつ長期間安全に投与できたこと，さら にOKT4/OKT8比の上昇で示される免疫学的増 強効果が認められたことによる。とくに本症例は 末梢血中リンパ球打よびその Tリンパ球サブ セット，さらに NK 細胞活性の経時的変化が観察 され, 本剂の免疫担当細胞への関与につき多くの 示唆に富む結果の得ら机た症例であった。

\section{4. 考察}

臨床の場に沶いて免疫賦活剤もしくは免疫調節 剂と称される薬剂が投与される場合，原則的には その生体が免疫学的に低下ないし狭義の不全状態 にあることが前提となる。

今回のわれわれの検討対象疾患であるび委儿性 汎細気管支炎 (DPB) や気管支拡張症 (BE) に沶 ける下気道感染症では, 果して生体免疫力が低下 しているか否かが問題であるが，すで筆者ら が報告したようにDPBでは，血中免疫グロブリ ンや末梢血リンパ球サブセットの解析から体液性 ならびに細胞性免疫能は低下して抢らず，むしろ 亢進状態にあることが判明している。したがって， DPBなどの疾患に执いて危疫賦活剤の投与が何 如なる臨床的意味を有するかは未だ結論が得られ ていない。

しかしながら，殊にDPB に揖いては経過中そ の病態の進行とともに，気道・中間領域感染症の 起炎菌が H. influenzae PS. pneumoniaeなどか ら最終的に $P$. aeruginosa に菌交代するのが通常 であり ${ }^{8)}$ 10), この難治性の P. aeruginosa 感染症 が DPB に和ける予後の重要な決定因子の 1 つで ある ${ }^{8)}$. 現在このP. aeruginosa に対しょり強力な 抗菌作用を有する新しい抗生物質が次々と開発さ れて来てはいるものの，こ机ら抗生物質の臨床上 の有効性については限界があるのも事実である。 これには，とくにDPBに扮いて病変の進展とと もに形態学的に $P$. aeruginosa 感染症が生じやす くから難治になることが一因であり ${ }^{9111}$ ，このため 局所に括ける免疫能の低下状態を考慮しなければ ならない。したがって P. aeruginosa を主体とす 
るグラム陰性桿菌に対する生体の感染防御機構を 増強する, 免疫賦活剤ないし免疫調節剂の臨床応 用も，末期状態や CS 投与などを除いて明らかな 全身的免疫不全状態がないDPBに拈いても試み られるべき治療法の 1 つと考光られる。

Forphenicinol は低分子免疫調節剂であり, 感 染症和よび悪性腫瘍に括いてその効果を期待され ているが，とくに感染免疫に関しては動物実験で P. aeruginosaなどの感染症に対する防御効果を 有すること年が報告されている.ささら臨床面で は石橋らによる非定型抗酸菌症掞よび肺結核症に 抢ける有効例の報告 ${ }^{12)}$ の他, 松本ら ${ }^{13)}$ によるP.aeruginosaによる重症下気感染症において, 本用が 臨床的に 9 例中 5 例で有効であり, 本剂投与によ り喀疢中のマクロファージと好中球が増加し, か つ in vitro での好中球の貪食能が六進することが 報告されている。

われわれが今回検討した 9 例中 8 例は基礎疾患 が DPB であり, かつ 9 例全ての感染起炎菌が $P$. aeruginosa ないしGNF-GNRであったため，一 部の例では本剂の投与経過中に呼吸不全の治療目 的で CS の投与や, 酸素療法を施行されて打り, か つ全例で各種の抗生物質が適宣投与された。した がって Forphenicinol の気道・中間領域感染症に 対する臨床効果の判定は必ずしも容易ではない が，本剂がかなり長期（最長562日，平均357日） にわたり安全に投与でさたため，各症例について それぞれ総合的な評価が可能であった。

臨床効果判定で本剂開始後, DPBの 1 例で基礎 疾患の安定化と日常生活動作の改善が認められた 有効と判定したが，他に DPB 3 例，BE 1 例で本 剂投与後臨床的に効果が得られて和り，これらの やや有効例も含めてその有効率をみると $55.6 \%$ で あった，通常の抗生物質や抗菌剂と異なり, Forphenicinolのような免疫調節剤では評価の指標の 設定は困難であるが，われわれは呼吸困難，日常 動作などの自覚症状と本剂使用前後の急性増悪回 数执よび免疫学的検查を重視した。また当初予想 されたことであるが，細菌学的にはすべての症例 で投与前と不変であり 1 例も除菌されず，胸部 X 線所見も変らず，これらは本剤の評価には適当で
ないと考光られた。

本剂投与による免疫学的パラメーターの推移を みると，末梢血中のリンパ球サブセットでは口

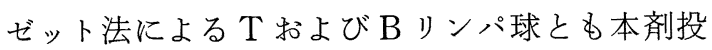
与前後の有意な変化を示さなかった。本剤による T, B リンパ球分面への影響については, Kumano ら ${ }^{14)}$ が肺癌などの担癌患者と肺結核症患者に打い て，杰た寺門ら ${ }^{15)}$ が皮膚癌患者に执いてそれぞれ 本剂投与により正常化したとする報告があるが， 石橋ら ${ }^{12)} ら$ 主に肺結核症例に执いて，われわれと 同様の観察結果を報告して和り，T扣よび B リン パ球分画は本剤投与前から正常域にあったためと している。また，モノクローナル抗体を用いた T リンパ球サブセットに対する影響についての研究 では，Forphenicinol 投与により肺癌および胃癌 患者に拈いて OKT8陽性細胞が低下寸る ${ }^{16)}$ こ が報告されている。

今回のわれわれの成績でもサプレッサーT細 胞と考えられるOKT8陽性細胞が本剂投与によ り減少する傾向を示し, そのため OKT4/OKT8比 すなわちへルパー/サプレッサー比の軽度上昇す る例が多く認められ, Forphenicinol がこれら T リンパ球レベルで免疫学的活性化の方向に作用 し, 抗体産生能を六進させる可能性が示唆された。 さらに，本剤による NK 細胞活性への影響につ いて, Kumano ら ${ }^{14)}$ は肺癌㐨よび肺結核症患者に 招いて特に明らかな傾向を認めなかったとしてい るが，今回の検討でも全体の成績では投与前後で 有意な差違は認められなかった。これは，とくに DPB では元来 $\mathrm{NK}$ 細胞活性は，健常者とほ涪同 等の值を示す17)ためであろらと考兄られる。

本論文で呈示した症例では，Forphenicinol 投 与と, 免疫学的パラメーターとの相関関係が比較 的明白に示されていると考学られる。とくに前述 のよらに本剂開始後 OKT8陽性細胞が減少し, 相 対的に OKT4陽性細胞が増加，このため OKT4/ OKT8比が上昇し，本剤投与期間中比較的高い值 を維持していたが，中止後これらのパラメーター が投与開始前に逆戻りしている。また, NK 細胞活 性では，本剂投与開始直後から低下して拉り以後 も低值を示したが，中止後さらに低下が認められ 
たことから，むしろ基礎疾患の重症度に基づく変 化で, Forphenicinol がある程度は NK 細胞活性 を上昇させる作用を有していたとする解釈も可能 である、いずれにしても，呈示症例は重症例であ り, P. aeruginosa の持続感染が長期にわたり，か つCS 継続投与下にある症例にも拘らず，抒招よ そ 1 年の間比較的安定した経過をとり得たのは本 剤の影響であった可能性が示唆される。

以上, DPBを主な基礎疾患とする気道・中間領 域感染症 9 例に怙ける低分子免疫調節剂 Forphenicinol の使用成績について，とくに免疫学的 各種パラメーターの検討を中心に述べたが, 本剤 はその感染免疫に対する増強作用が期待され，か つきわめて安全性の高い薬剂であるため，今後も 本剂の長期投与に関する有効性の検討と臨床応用 が望まれる。

本論文の要旨は第59回日本感染症学会総会 (1985年 5 月, 沖縄）にて発表した。

\section{文献}

1) Umezawa, H.: Recent advances in bioactive microbial secondary metabolites. Jap. J. Antibiotics. 30(Suppl.) : 138-163, 1977.

2) Aoyagi, T., Yamamoto, T., Kajiri, K., Kojima, F., Hamada, M., Takeuchi, T. \& Umezawa, H.: Forphenicine, an inhibitor of alkaline phosphatase produced by actinomycetes. J. Antibiotics, 31:244-246, 1978.

3）梅沢浜夫：本邦に拉ける新抗癌剤開発の現況。将 来への展望一抗癌性抗生物質を中心に一. 癌と化 学療法, 8:867-876, 1981.

4）石塚雅章：低分子免疫調節物質. 癌と化学療法, 9(Suppl. I) : 86-91， 1982.

5) Ishizuka, M., Ishizaki, S., Masuda, T., Momose, A., Aoyagi, T., Takeuchi, T. \& Umezawa, H. : Studies on effects of forphenicinol on immune responses. J. Antibiotics, 35 : 1042-1048, 1982.

6) Ishizuka, M., Masuda, T., Kanbayashi, N., Watanabe, Y., Matsuzaki, M. Sawazaki, Y., Ohkura, A., Takeuchi, T. \& Umezawa, H.: Antitumor effect of forphenicinol, a low molecular weight immunomodifier, on murine tran- splantable tumors and microbial infections. J. Antibitics, 35 : 1049-1054, 1982.

7) 吉村邦彦, 内田好彦, 中谷龍王, 蝶名林直彦, 中 森祥隆, 中田紘一郎, 谷本普一: びまん性沉細気 管支炎の免疫学的研究一とくに本症に和ける T リンパ球サブセットの解析一, 日胸疾会誌, 22 ： 992-999, 1984.

8）谷本普一, 蒲田英明, 荒井信吾, 守永眞一, 岡野 弘, 原満, 本間日臣, 田村昌士, 山中 晃 : びまん性沉細気管支炎一15剖検例の検討一.内科, $41: 906-914,1978$.

9）谷本普一, 立花昭生, 中森祥隆, 蝶名林直彦, 中 谷龍王, 中田紘一郎, 岡野 弘, 松岡ひろ子：緑 膿菌呼吸器感染症の病態と治療. 日胸, 40 : 485-492, 1981.

10）中森祥隆, 中谷龍王, 蝶名林直彦, 立花昭生, 中 田紘一郎, 岡野 弘, 谷本普一: びまん性汎細気 管支炎気道・中間領域感染症に括ける抗生物質療 法の検討。日胸疾会誌, $21: 693-698,1983$.

11）吉村邦彦, 中田紘一郎：気道・中間領域感染症の 成立。臨床之細菌，11：465-470，1984。

12）石橋凡雄, 高本正䃼, 篠田 厚, 杉山浩太郎：低 分子免废調節剤 Forphenicinol の臨床研究. Jap. J. Antibiotics, 37 : 185-197, 1984.

13) Matsumoto, K., Nagatake, T., Rikitomi, N., Uzuka, Y. \& Harada, T.: Clinical trial of a new immunomodulator, forphenicinol, againstt severe respiratory infections. Proceedings of the 13th International Congress of Chemotherapy. Vienna, Austria, Aug. 28-Sept. 2, 1983.

14) Kumano, N., Nakai, Y., Suzuki, S., Oizumi, K. \& Konno, K.: Human lymphocyte response to forphenicinol, a small molecular immunomodifier, 13th International Cancer Congress, Sept. 8-15, 1982. (Seattle).

15）寺門武文, 斉藤一義, 田嶋公子, 宮里 肇, 鈴木 正, 池田重雄：新しいBiological Response Modifier, Forphenicinol の Phase I Study. 癌と 化学療法, 10：2309-2317, 1983.

16）微生物化学研究所, 萬有製薬株式会社共編：Forphenicinol 第 5 回研究会 (1983).

17）吉村邦彦, 蝶名林直彦, 中谷龍王, 中森祥隆, 中 田紘一郎, 谷本普一：びまん性沉細気管支炎に和 ける Natural Killer 細胞活性に関する研究. 日胸 疾会誌, 投稿中. 
Clinical and Immunological Studies on Forphenicinol, a Low Molecular Weight Immunomodulator, in Chronic Respiratory Infections

Kunihiko YOSHIMURA, Naohiko CHONABAYASHI, Tatsuo NAKATANI, Yoshitaka NAKAMORI, Koichiro NAKATA \& Hiroichi TANIMOTO

Department of Respiratory Diseases, Toranomon Hospital, Tokyo, Japan

We studied clinical and immunological effectiveness of forphenicinol, a low molecular weight immunomodulator, in nine patients with chronic respiratory tract infection. Underlying diseases were diffuse panbronchiolitis in 8 cases and bronchiectasis in one case, and as a causative organism Pseudomonas aeruginosa was isolated in 7 cases, and GNF-GNR was in 2 cases. Forphenicinol was orally administered at the dose of 50 or $100 \mathrm{mg}$ per day for 30 to 562 days (average 357 days), and 3.0 to $56.2 \mathrm{~g}$ (average $31.8 \mathrm{~g}$ ) totally. The results obtained were as follows.

1. Forphenicinol showed effectiveness in $55.6 \%$ of 9 cases including fair responses.

2. Neither $P$. aeruginosa nor GNF-GNR was eradicated in all 9 cases after the treatment with forphenicinol.

3. Forphenicinol caused neither adverse effects nor abnormal laboratory findings.

4. From the point of immunological view, $\mathrm{T}$ and $\mathrm{B}$ lymphocyte subsets studied by rosette methods did not change significantly, but a subset of suppressor $\mathrm{T}$ lymphocyte detected by OKT8 monoclonal antibody showed some decrease. However, there was no significant change in NK cell activity after the treatment with forphenicinol.

Because forphenicinol shows little toxicity, is capable of beening administered for a long time and would enhance the antibody production by reducing suppressor $\mathrm{T}$ cells, we conclude that it is worthwhile to administer this drug for the patients with chronic respiratory infections. 